\title{
Grade Card Model using Fuzzy Logic
}

\author{
G.Vasanti
}

Abstract-The Students domain provides us a treasure to unveil many interesting applications of Fuzzy Logic, which in turn support the Education System for better decision making. The base of the Education System is the Students Performance which is represented by his/her Grade. This article presents a model for developing a Grade Card for a Graduate Student using Fuzzy Logic.

Keywords- Fuzzy Logic, Performance Evaluation, education System, membership function, Fuzzy Associate Memory.

\section{INTRODUCTION}

In 2011, Zahari[8], presented Grade Calculation model using Fuzzy Logic System to calculate the final grade of Data Structure and Algorithms for student's based on three categories which are cognitive, psychomotor and affective.In same year, Ramjeet Singh Yadav, utilized Fuzzy Expert System (FES) to estimate the performance of a student.

In2013, Rusmiarietal.[9], tried to resolve the issues related to students achievements using fuzzy logic.

In 2015, Vasantiand Viswanadham[11], [13], presented a restrictive model utilizing Intuitionistic touchy set (IFS) to explain shortcoming and inconsistency related with picking the understudy expected execution in a course utilizing systematized Euclidean division method by investigating the parcel between each understudy and predicted subject execution. In thesame year, the first author proposed Counseling/Performance Analysis system driven by fuzzy logic technique by providinga better self performance analysis based on counseling or performance test to the students. Meenakshi and Pankaj[12], evaluated student's academic performance through a new approach with the support of fuzzy logic, taking into consideration the attendance, internal and external marks using fuzzy logic based on Mamdani technique.

In 2016, Barlybayevaetal[15], to spread ICT in education and to get a qualitative education,Therefore, proposed a fuzzy model of execution assessment of understudies through the foundation of execution. Vasanti and VenkataRao, demonstrated a general best/favored proficient request model over observe a Best Performer (BP), an inside and out understudy subject to all qualities of the understudy, which merges I.Q, time the authorities, introduction aptitudes, quick, thriving, moral obligations, and so on. Matej [16], comprehended the problem to evaluate the competency development in an individual, which was assessed with $360^{\circ}$ feedback using fuzzy logic tools.

The success of an Educational Institution is assessed by the level of Grades scored by their college students. On the other hand, Students impression about assessment and their

Revised Manuscript Received on April 12, 2019.

G.Vasanti, Professor, Basic Science and Humanities Department, Aditya Institute of Technology and Management,Tekkali, Srikakulam(dist), Andhra Pradesh, India, pin-532201.(E-mail: vasanti_u@yahoo.co.in) approaches to learning are changing with Modernization. In general the Educational Institutes are awarding a student a Grade based on the students performance in internal and external examinations of the type:

\begin{tabular}{|l|c|c|c|}
\hline $\begin{array}{l}\text { Percent } \\
\text { age }\end{array}$ & $\begin{array}{l}\text { Grade } \\
\text { Points }\end{array}$ & $\begin{array}{l}\text { Letter } \\
\text { Grade }\end{array}$ & $\begin{array}{l}\text { Performance } \\
\text { Index }\end{array}$ \\
\hline $95-100 \%$ & 10 & A+ & Excellent \\
\hline $85-<95 \%$ & 9 & A & Very Good \\
\hline $75-<85 \%$ & 8 & $\mathrm{~B}^{+}$ & Good \\
\hline $65-<75 \%$ & 7 & $\mathrm{~B}$ & Average \\
\hline $55-<65 \%$ & 6 & $\mathrm{C}$ & Fair \\
\hline $40-<55 \%$ & 5 & $\mathrm{P}$ & Pass \\
\hline$<40 \%$ & 0 & $\mathrm{~F}$ & (Fail) \\
\hline
\end{tabular}

In view of this, the author planned a model to motivate the students community towards the improvement in different attitudes like attendance, self study, knowledge gain in technology usage, ethical attitude which in turn supports to develop a beautiful society. Hence the author had designed this Grade Card Model using Fuzzy Logic.

\section{METHODOLOGY}

Here the author presents a Model "the grade Card of a student using Fuzzy logic".

Fuzzification joins the course of action of progress ing fresh impacting force into evaluation of joint exertion for linguis-tic terms of padded sets. Past what many would consider conceivable is utilized to relate an examination to each semantic term. The real stage in utilizing delicate reason inside this model is to see the parameters that will be fuzzified and to pick their individual degree of characteristics. The last conceded result of this affiliation is the inspiration for each perfor-mance parameter. A Fuzzy Inference System (FIS) hardens information and yield assurance limits, fuzzification, content with intuition motor, Fuzzy standard base and defuzzification. Fig. 1 demonstrates the blueprint of the complete process.

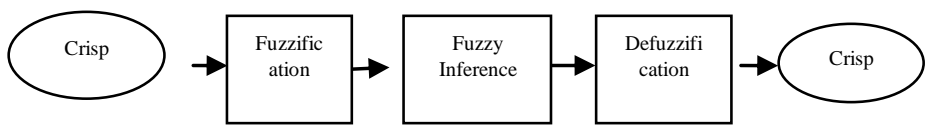

Figure 1: Fuzzy Logic Model

\section{FUZZIFICATION}

The input data can be categorized for each student in two modules: Academics and Non-Academics. Under Academics for each subject/course, $k=1,2, \ldots, 10$ attributes like attendance, internal marks, external marks, seminar 
presentation marks, Faculty review score, course related technology/ application usage in the seminar presentation are considered and under Non-Academics, disciplinary action (if any based on the action taken by the authorized chairman of the disciplinary committee), participation in activities reviewed by class teacher, behavior reviewed by class teacher, behavior reviewed by peer group.
Measuring students performance involves assigning a number to mirror a teacher's presentation in the obvious estimations. Believe it or not, numbers are not required. Names, for example, "shocking", "stunning", "av-erage", "reasonable" and "poor" are utilized. Rating size of information and yield parameters is portrayed into abnormality ent portrayals as given in the table 1 and 2 .

TABLE-I: Attribute Analysis in the Grade Card

\begin{tabular}{|c|c|c|c|c|}
\hline & & Attribute & Scale & Performance \\
\hline \multirow{10}{*}{$\begin{array}{l}\text { Course } 1,2 \text {, } \\
3 \text {. }\end{array}$} & A1 & Attendance & $0-10$ & \multirow{6}{*}{ Academics } \\
\hline & $\mathrm{A} 2$ & Internal marks & $0-10$ & \\
\hline & A3 & External marks & $0-10$ & \\
\hline & A4 & Seminar presentation & $0-10$ & \\
\hline & A5 & Faculty review score & $0-10$ & \\
\hline & A6 & $\begin{array}{l}\text { Course related Technology/ } \\
\text { Application }\end{array}$ & $0-10$ & \\
\hline & A7 & $\begin{array}{l}\text { Disciplinary action (if any based } \\
\text { on the action taken by the } \\
\text { authorized chairman of the } \\
\text { disciplinary committee) }\end{array}$ & $0-10$ & \multirow{4}{*}{$\begin{array}{l}. \\
. \\
. \\
. \\
\text { Non- } \\
\text {.Academics }\end{array}$} \\
\hline & A8 & $\begin{array}{l}\text { Activity participation review by } \\
\text { class teacher }\end{array}$ & $0-10$ & \\
\hline & A9 & Behavior review by class teacher & $0-10$ & \\
\hline & A10 & Behavior review by peer group & $0-10$ & \\
\hline
\end{tabular}

For students, the data regarding the above 10 attributes is transformed into linguistic variable as shown in Table are required to be focused. Then the information collected

II, supporting the Grade of the student.

TABLE-II:Linguistic variable For Each Attribute

\begin{tabular}{|c|c|c|}
\hline A & Attribute & Linguistic Variable \\
\hline A1 & Attendance & $\begin{array}{l}\text { \{Very Low, Low, Lower Medium, Medium, } \\
\text { Higher } \\
\text { Medium, High, Very High }\}\end{array}$ \\
\hline A2 & Internal marks & $\begin{array}{l}\text { \{Very Low, Low, Lower Medium, Medium, } \\
\text { Higher } \\
\text { Medium, High, Very High }\}\end{array}$ \\
\hline A3 & External marks & $\begin{array}{l}\text { \{Very Low, Low, Lower Medium, Medium, } \\
\text { Higher Medium, High, Very High }\}\end{array}$ \\
\hline A4 & Seminar presentation & $\begin{array}{l}\text { \{Very Low, Low, Lower Medium, } \\
\text { Medium, Higher Medium, High, } \\
\text { Very High }\}\end{array}$ \\
\hline A5 & Faculty review score & $\begin{array}{l}\text { \{Very Low, Low, Lower Medium, Medium, } \\
\text { Higher } \\
\text { Medium, High, Very High }\}\end{array}$ \\
\hline
\end{tabular}




\begin{tabular}{|l|l|l|} 
A6 & $\begin{array}{l}\text { Course related } \\
\text { Technology/ Application }\end{array}$ & $\begin{array}{l}\text { \{Very Low, Low, Lower Medium, } \\
\text { Medium, Higher Medium, High, Very } \\
\text { High }\}\end{array}$ \\
\hline A7 & $\begin{array}{l}\text { Disciplinary action (if any based on the } \\
\text { action taken by the authorized chairman } \\
\text { of the disciplinary committee })\end{array}$ & $\begin{array}{l}\{\text { Very Low, Low, Lower Medium, Medium, } \\
\text { Higher Medium, High, Very High }\}\end{array}$ \\
\hline & $\begin{array}{l}\text { Activity participation review by class } \\
\text { teacher }\end{array}$ & $\begin{array}{l}\{\text { Very Low, Low, Lower Medium, Medium, } \\
\text { Higher } \\
\text { Medium, High, Very High }\}\end{array}$ \\
\hline A9 & Behavior review by class teacher & $\begin{array}{l}\{\text { Very Low, Low, Lower Medium, Medium, } \\
\text { Higher Medium, High, Very High }\}\end{array}$ \\
\hline & & $\begin{array}{l}\text { \{Very Low, Low, Lower Medium, } \\
\text { Medium, Higher Medium, High, Very } \\
\text { High }\}\end{array}$ \\
\hline A10 & Behavior review by peer group & \\
\hline
\end{tabular}

The Fuzzification process involves the input variables to be converted into suitable value in the range of $[0,10]$. The range is categorized into 7 linguistic variables which are "Very Low", "Low", "Lower Medium", "Medium", "Higher Medium", "High", "Very High" as shown in Table-II.

\section{TABLE III: Linguistic variable for each Performance}

\begin{tabular}{|l|l|}
\hline Performance & Linguistic Variable \\
\hline & $\begin{array}{l}\{\text { Excellent(A+), Very Good(A), } \\
\left.\text { Good( } \mathrm{B}^{+}\right), \text {Average(B), Fair(C), } \\
\text { Pass }(\mathrm{P})\}\end{array}$ \\
\hline Academic & $\begin{array}{l}\{\text { Excellent(A+), Very Good(A), } \\
\left.\text { Good(B }{ }^{+}\right), \text {Average(B), Fair(C), } \\
\text { Non- } \cdot \cdot \\
\text { Academic }\end{array}$ \\
\hline
\end{tabular}

The Grades/output regarding students Performance is divided into 7 linguistic variables which are "Excellent $\left(\mathrm{A}^{+}\right)$", $\quad$ "Very $\operatorname{Good}(\mathrm{A})$ ", $\quad$ "Good(B $\left.\mathrm{B}^{+}\right)$", "Average(B)", "Fair(C)", "Pass(P)" as shown in Table III.

The crisp values of different attributes are converted to the fuzzy value in range $\{0,1\}$.Here, Trapezoidal function is used to generate the membership function.

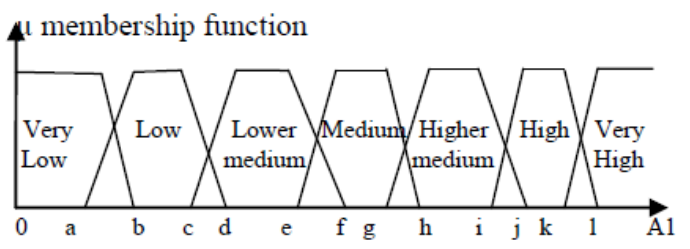

Fig- 2: Membership function for attribute 1(A1)

$$
\mu_{A 1}(x)=\left\{\begin{array}{c}
1, x<a \\
\frac{x-a}{b-a}, a \leq x \leq b \\
1, b \leq x \leq c \\
\frac{x-c}{d-c}, c \leq x \leq d \\
1, d \leq x \leq e \\
\frac{x-e}{f-e}, e \leq x \leq f \\
1, f \leq x \leq g \\
\frac{x-g}{h-g}, g \leq x \leq h \\
1, h \leq x \leq i \\
\frac{x-i}{j-i}, i \leq x \leq j \\
1, j \leq x \leq k \\
\frac{k-x}{l-k}, k \leq x \leq l \\
1, x>l
\end{array}\right.
$$

A membership function for a fuzzy set A1 in Fig. 2 on $X$, is defined as $\mu_{\mathrm{A} 1}: X \rightarrow[0,1]$, where each $\mathrm{X}$ of $\mathrm{X}$ is mapped to a value between 0 and 1 . This value, called as membership value, quantifies the grade of membership of $\mathrm{X}$ in $\mathrm{X}$ to the fuzzy set

A1. Since Trapezoidal function is applied, so equation (1) is used to convert all the crisp value from the input to a fuzzy value, where $a<b<c<d<e<f<g<h<I<$ $j<k<l$. The value of $a$ is $1, b$ is $2, c$ is $3, d$ is $4, e$ is $4.5, f$ is 5, $g$ is 5.5, h is 6,I is 6.5,j is 7, $k$ is $8, l$ is 9 .

\section{FUZZY INFERENCE\& RESULTS}

Fuzzy inference engine converts an input function to an output function using the fuzzy inference base. Among the Fuzzy Inference Techniques, Mamdani. In this study, we use the operators MIN and AND as inference rules to combine input attribute 1 (A1) and attribute 2 (A2) as:

$\mu_{\mathrm{A} 1} \cap \mu_{\mathrm{A} 2}=\min \left[\mu_{\mathrm{A} 1}(\mathrm{x}), \mu_{\mathrm{A} 2}(\mathrm{x})\right]$

$\mu \mathrm{A} 1$ and $\mu \mathrm{A} 2$ are membership functions that define the fuzzy sets $\mathrm{A} 1$ and $\mathrm{A} 2$, respectively, on the whole set $\mathrm{X}$. The intersection of fuzzy sets $\mathrm{Ak}, \mathrm{k}=1,2,3 \ldots, 10$ is a fuzzy set defined by the membership function in equation (2). 
Then the creation of fuzzy rule are produced based on value of FAM as show below where $x$ is fuzzy value:

IF A1 is Q1 is $\operatorname{No}(x)$ AND Q2 is $\operatorname{No}(x)$ THEN Student Performance regarding Attendance is Weak $(x)$

\begin{tabular}{|c|c|c|c|c|c|c|c|}
\hline A\&A1 & $\begin{array}{l}\text { Very } \\
\text { Low }\end{array}$ & $\begin{array}{l}\text { Lo } \\
\mathrm{W}\end{array}$ & $\begin{array}{l}\text { Low } \\
\text { er } \\
\text { Medi } \\
\text { um }\end{array}$ & $\begin{array}{l}\text { Me } \\
\text { diu } \\
\text { m } \\
\text { Pas }\end{array}$ & $\begin{array}{l}\text { Higher } \\
\text { Mediu } \\
\mathrm{m}\end{array}$ & High & $\begin{array}{l}\text { Very } \\
\text { High } \\
\text { Average }\end{array}$ \\
\hline Low:0 & Fail & Fail & Pass & $\mathrm{s}$ & & & \\
\hline $\begin{array}{l}\text { Low:0. } \\
5\end{array}$ & Fail & $\begin{array}{l}\text { Pas } \\
\text { S }\end{array}$ & Fair & Fair & Fair & $\begin{array}{l}\text { Aver } \\
\text { age }\end{array}$ & Average \\
\hline $\begin{array}{l}\text { Lower } \\
\text { Mediu } \\
\text { m }\end{array}$ & Pass & Fair & Fair & Fair & $\begin{array}{l}\text { Avera } \\
\text { ge }\end{array}$ & $\begin{array}{l}\text { Aver } \\
\text { age }\end{array}$ & Good \\
\hline $\begin{array}{l}\text { Mediu } \\
\mathrm{m}\end{array}$ & Pass & Fair & Fair & $\begin{array}{l}\text { Ave } \\
\text { rage }\end{array}$ & $\begin{array}{l}\text { Avera } \\
\text { ge }\end{array}$ & Good & Good \\
\hline $\begin{array}{l}\text { Higher } \\
\text { Mediu } \\
\text { m }\end{array}$ & Pass & Fair & $\begin{array}{l}\text { Aver } \\
\text { age }\end{array}$ & $\begin{array}{l}\text { Ave } \\
\text { rage }\end{array}$ & Good & Good & $\begin{array}{l}\text { Very } \\
\text { Good }\end{array}$ \\
\hline High & Fair & $\begin{array}{l}\text { Ave } \\
\text { rage }\end{array}$ & $\begin{array}{l}\text { Aver } \\
\text { age }\end{array}$ & $\begin{array}{l}\text { Goo } \\
\text { d }\end{array}$ & Good & $\begin{array}{l}\text { Very } \\
\text { Good }\end{array}$ & $\begin{array}{l}\text { Excelle } \\
\text { nt }\end{array}$ \\
\hline $\begin{array}{l}\text { Very } \\
\text { High }\end{array}$ & $\begin{array}{l}\text { Aver } \\
\text { age }\end{array}$ & $\begin{array}{l}\text { Ave } \\
\text { rage }\end{array}$ & $\begin{array}{l}\text { Goo } \\
\mathrm{d}\end{array}$ & $\begin{array}{l}\text { Goo } \\
\text { d }\end{array}$ & $\begin{array}{l}\text { Very } \\
\text { Good }\end{array}$ & $\begin{array}{l}\text { Excel } \\
\text { lent }\end{array}$ & $\begin{array}{l}\text { Excelle } \\
\text { nt }\end{array}$ \\
\hline
\end{tabular}

TABLE- IV: FUZZY INFERENCE TABLE FOR ATTRIBUTES A1 AND A2:

FAM in table IV show the result after applied the operator MIN and intersection AND in equation (2).

\section{DEFUZZIFICATION}

In any Fuzzy system or Fuzzy model, the output is pleasant. It is less unpredictable to take another choice if the yield is tended to by a solitary scalar total. This capability in a pleasant set to a solitary new worth is defuzzification and is turn reasoning of fuzzification.

For this condition, the explanation behind mixing of wholes (COS) approach is utilized and the resultant decision most remote point is work by taking the logarithmic aggregate of the yields from each contributing pleasing sets $\mathrm{Ak}$. The defuzzified worth is given by

$$
\operatorname{COS}=\frac{\sum_{i=1}^{7} x_{i} \sum_{k}^{10} \mu_{A k}\left(x_{i}\right)}{\sum_{i=1}^{7} \sum_{k}^{10} \mu_{A k}\left(x_{i}\right)}
$$

where $\mathrm{k}$ is the number of fuzzy sets and $\mathrm{i}$ is the number of fuzzy variables.

\section{CONCLUSION}

The Grade Card for B.Tech students will benefit in improving their performance in more truly which in turn motivate the students to maintain all the attributes listed under Academics and Non-Academic performance. This improves the standards of the student, an Educational Institution and in turn our Society.

\begin{tabular}{|c|c|c|}
\hline \multicolumn{3}{|c|}{$\begin{array}{l}\text { GRADE CARDName: Miss K.Sravya } \\
\text { H.T.No.:17A51A0541 }\end{array}$} \\
\hline & Attribute(Academics) & Scale \\
\hline A1 & Attendance & High \\
\hline A2 & Internal marks & Very High \\
\hline A3 & External marks & Very High \\
\hline A4 & Seminarpresentation & High \\
\hline A5 & Faculty review score & High \\
\hline A6 & $\begin{array}{l}\text { Course related Technology/ } \\
\text { Application }\end{array}$ & $\begin{array}{l}\text { Higher } \\
\text { Medium }\end{array}$ \\
\hline \multicolumn{3}{|c|}{ Attribute(Non-Academics) } \\
\hline A7 & $\begin{array}{l}\text { Disciplinary action (if any based } \\
\text { on the action taken by the } \\
\text { authorized chairman of the } \\
\text { disciplinary committee) }\end{array}$ & Very Low \\
\hline A8 & $\begin{array}{l}\text { Activity participation review by } \\
\text { class teacher }\end{array}$ & $\begin{array}{l}\text { Higher } \\
\text { Medium }\end{array}$ \\
\hline A9 & Behavior review by class teacher & High \\
\hline A10 & Behavior review by peer group & High \\
\hline
\end{tabular}

\section{ACKNOWLEDGMENT}

The author would like to thank the AITAM management for their support and encouragement.

\section{REFERENCES}

1. Bruce Schneier, "Applied Cryptography", second ed., John Wiley \& Sons, New York, 1996.

2. Anoop MS, "Public key cryptographyApplications Algorithms and Mathematical Explanations", Tata Elxsi Ltd, India,.2008

3. https://searchsecurity.techtarget.com

4. https://www.cryptomathic.com/newsevents/blog/what-is-a-digital-signature-what-itdoes-how-it-works

5. https://www.securedsigning.com/why-securedsigning 